\title{
Study on the Reduction Behaviour of Nickel Doped Molybdenum Trioxide by Using Carbon Monoxide as Reductant
}

\author{
Alinda Samsuri, Fairous Salleh, Tengku Shafazila Tengku Saharuddin, Rizafizah Othaman, and Mohd. \\ Ambar Yarmo
}

\begin{abstract}
The reduction behaviour of molybdenum trioxide, $\left(\mathrm{MoO}_{3}\right)$ and nickel $(\mathrm{Ni})$ doped $\mathrm{MoO}_{3}$ using carbon monoxide (CO) as reductant was investigated by temperature programmed reduction (TPR) and characterized by X-ray diffraction (XRD), Brunauer-Emmett-Teller (BET) and transmission electron microscope analysis (TEM). The reduction characteristics of $\mathrm{MoO}_{3}$ to $\mathrm{MoO}_{2}$ were examined up to temperature $700{ }^{\circ} \mathrm{C}$ and continued with isothermal reduction by 20 vol. \% CO in nitrogen. The studies show that, TPR spectra of doped $\mathrm{MoO}_{3}$ slightly shift to a lower temperature as compared to the undoped $\mathrm{MoO}_{3}$ which begins at $630{ }^{\circ} \mathrm{C}$. The interaction between nickel and molybdenum ions leads to this slightly decrease of the reduction temperature of $\mathrm{Ni}$ doped $\mathrm{MoO}_{3}$. Analysis using XRD confirmed, the addition of Ni enhances the reducibility of $\mathrm{MoO}_{3}$. By addition of $\mathrm{Ni}$, complete reduction to $\mathrm{MoO}_{2}$ were take place at only 30 minutes starting of the isothermal reduction at $700{ }^{\circ} \mathrm{C}$. Whereas, for undoped $\mathrm{MoO}_{3}$ it takes about 60 minutes to completely reduce to $\mathrm{MoO}_{2}$. However, excess of $\mathrm{CO}$ brings to the formation of molybdenum carbide $\left(\mathrm{Mo}_{2} \mathrm{C}\right)$. Based on the results, it is confirmed addition of $\mathrm{Ni}$ to $\mathrm{MoO}_{3}$ has a remarkable influence by reducing temperature in the reduction process. The ability to enhance the reducibility involved in $\mathrm{MoO}_{3}$ may be associated to the presence of nickel molybdate, $\mathrm{NiMoO}_{4}$ compound.
\end{abstract}

Index Terms-Carbon monoxide, molybdenum trioxide, nickel, reduction.

\section{INTRODUCTION}

Metallic molybdenum, having a body centered cubic crystal structure with a melting point of $2619^{\circ} \mathrm{C}$ and a density of $10.22 \mathrm{~g} / \mathrm{cm}^{3}$ [1]. Due to superior properties such as excellent in mechanical, thermal and electric properties and

Manuscript received February 5, 2015; revised May 20, 2015. This work was financially and technically supported by Ministry of Higher Education and Universiti Pertahanan Nasional Malaysia for funding staff scholarships, Universiti Kebangsaan Malaysia for funding this project under research grant number FRGS/2/2013/TK06/UKM/02/3, ETP-2013-066, TD-2014-024, BKBP-FST-K003323-2014 and Centre of Research and Innovation Management, Universiti Kebangsaan Malaysia for the instruments facilities.

Alinda Samsuri is with School of Chemical Science \& Food Technology, Faculty of Science and Technology, Universiti Kebangsaan Malaysia, 43600 Bangi, Selangor, Malaysia, and on study leave from Centre for Defence Foundation Studies, Universiti Pertahanan Nasional Malaysia, Kem Sungai Besi, 57000 Kuala Lumpur, Malaysia (e-mail: alindasamsuri@gmail.com).

Fairous Salleh, Tengku Shafazila Tengku Saharuddin, Rizafizah Othaman, and Mohd. Ambar Yarmo are with School of Chemical Science \& Food Technology, Faculty of Science and Technology, Universiti Kebangsan Malaysia, 43600 Bangi, Selangor, Malaysia (e-mail: fairoussalleh@gmail.com, rizafizah@ukm.edu.my,ambar@ukm.edu.my). good corrosion resistance make them ideally used as an alloying agent for manufacturing steels, cast irons, and super alloys to increase their mechanical strength, hardness, swiftness and resistance to corrosion and wearing [2].

As a catalyst, the reduction behaviour and the degree of reduction of the molybdenum species were highly important in such application. The reduction process of $\mathrm{MoO}_{3}$ is not a simple process and involved different mechanism depending on various factors such as temperature, concentration of reduction gas used and additives to the $\mathrm{MoO}_{3}$. In general, the two-stage flow scheme $\left(\mathrm{MoO}_{3} \rightarrow \mathrm{MoO}_{2}, \mathrm{MoO}_{2} \rightarrow \mathrm{Mo}\right)$ is employed in order to minimize the formation of volatile molybdenum species that would be generated at high temperature required to obtain molybdenum in a single stage conversion of the molybdenum precursor [3].

Reduction of $\mathrm{MoO}_{3}$ by hydrogen is one of the methods used to obtain metallic molybdenum of high purity. Many excellent reports studying reduction of $\mathrm{MoO}_{3}$ to Mo with hydrogen have been published [4]-[6]. Generally, the two-step hydrogen reduction process to produce pure molybdenum powders is well known [7]. First stage reduction occurs in the temperature range of $450-650{ }^{\circ} \mathrm{C}$, and reduces the input material to $\mathrm{MoO}_{2}$. Second stage reduction is performed in the $1000-1100{ }^{\circ} \mathrm{C}$ range, and this process results in molybdenum metal. Nevertheless, hydrogen used as a reducing agent of $\mathrm{MoO}_{3}$ reduction is expensive.

Carbon is also used to reduce $\mathrm{MoO}_{3}$ at elevated temperature $\left(600-1200{ }^{\circ} \mathrm{C}\right)$. When metal oxides react with carbon, one of the reaction products would be gaseous and could be readily separated from the solid reaction products [8], [9]. This means that the use of carbon as a reducing agent can eliminate the need for an additional process that is a challenging task with reactive metals to separate the reaction products.

Therefore, it would be highly desirable to develop an alternative process to manufacture molybdenum. Reduction of $\mathrm{MoO}_{3}$ by using $\mathrm{CO}$ as reductant was recommended as an alternative process for producing molybdenum. Reduction of $\mathrm{MoO}_{3}$ to $\mathrm{MoO}_{2}$ by $\mathrm{CO}$ was suggested to follow two reduction stages which are shown as equation (1) and (2). However, it is limited of studies to use $\mathrm{CO}$ as reductant for reduction of $\mathrm{MoO}_{3}$ to $\mathrm{MoO}_{2}$.

$$
\begin{gathered}
4 \mathrm{MoO}_{3}+\mathrm{CO} \rightarrow \mathrm{Mo}_{4} \mathrm{O}_{11}+\mathrm{CO}_{2} \\
\mathrm{Mo}_{4} \mathrm{O}_{11}+3 \mathrm{CO} \rightarrow 4 \mathrm{MoO}_{2}+3 \mathrm{CO}_{2}
\end{gathered}
$$

The reduction of $\mathrm{MoO}_{3}$ to $\mathrm{MoO}_{2}$ is the crucial stage in the production of metallic molybdenum. Reference [10] reported 
that the reduction of $\mathrm{MoO}_{3}$ to $\mathrm{MoO}_{2}$ by using hydrogen consists of two reduction stages, namely $\mathrm{Mo}^{6+} \rightarrow \mathrm{Mo}^{5+}$ and $\mathrm{Mo}^{5+} \rightarrow \mathrm{Mo}^{4+}$. It seems that during the reduction of $\mathrm{MoO}_{3}$, $\mathrm{MoO}_{3}$ is firstly reduced to $\mathrm{Mo}_{4} \mathrm{O}_{11}$, then continued to $\mathrm{MoO}_{2}$.

Different reducing agent would give different reducibility effect. However, other elements are also needed to enhance the reducibility of metal oxide. For hydrogen reduction, other elements can generally influence $\mathrm{MoO}_{3}$ reduction by altering the reaction sequence by chancing nucleation and growth. Moreover, trace elements such as lanthanum, La and yttrium, $\mathrm{Y}$ are able to enhance the reduction rate of $\mathrm{MoO}_{3}$ [10]. Moreover, the addition of $\mathrm{Ni}$ to $\mathrm{MoO}_{3}$ can enhance their catalytic activity and stability by improving their oxygen storage capacity, reducibility, and resistance to sintering [11]. Hence, the used of $\mathrm{Ni}$ will encourage the reduction behaviour of $\mathrm{MoO}_{3}$.

The objective of this work is to study the reduction behaviour of $\mathrm{MoO}_{3}$ and to enhance the reduction performance of $\mathrm{MoO}_{3}$ by addition of other metal additive using mixture gas of $20 \mathrm{vol} . \% \mathrm{CO}$ in nitrogen as a reducing agent. In this study we report the preferable effects of the addition of different percentage of $\mathrm{Ni}$ species into $\mathrm{MoO}_{3}$ powders. The TPR and XRD analysis was performed to investigate the reduction behaviour of $\mathrm{Ni}$ doped $\mathrm{MoO}_{3}$ by comparing it to undoped species.

\section{EXPERIMENTAL PROCEDURE}

\section{A. Material}

All chemicals and solvents that have been used in these experiments e.g. commercially $\mathrm{MoO}_{3}$ powders from $\mathrm{BDH}$ Chemicals Ltd.., nickel nitrate, $\mathrm{Ni}\left(\mathrm{NO}_{3}\right)_{2} \cdot 6 \mathrm{H}_{2} \mathrm{O}$ from Merck and ethanol, $\mathrm{C}_{2} \mathrm{H}_{6} \mathrm{O}(99.5 \%)$ from Systerm ${ }^{\circledR}$ are pure and used as supplied.

\section{B. Catalyst Preparation}

Nickel doped molybdenum oxide were prepared by impregnation method using a $\mathrm{Ni}\left(\mathrm{NO}_{3}\right)_{2} \cdot 6 \mathrm{H}_{2} \mathrm{O}$ and $\mathrm{MoO}_{3}$ powder. The amount of $\mathrm{Ni}$ added was adjusted to be 3 and 9 mol\% of total metal cation or known as $3 \% \mathrm{Ni}-\mathrm{MoO}_{3}$ and $9 \%$ $\mathrm{Ni}-\mathrm{MoO}_{3}$. The both compounds were dissolved in water with additional of ethanol at $80{ }^{\circ} \mathrm{C}$ with stirring for 3 hours, producing a viscous mixture. The mixture was placed in an oven, dried at $110{ }^{\circ} \mathrm{C}$ overnight and finally calcined at $400{ }^{\circ} \mathrm{C}$ for 4 hours in air and then cooled to room temperature.

\section{Reduction of Molybdenum Trioxide, $\mathrm{MoO}_{3}$}

Reduction of the undoped $\mathrm{MoO}_{3}$ and $\mathrm{Ni}$ doped $\mathrm{MoO}_{3}$ was carried out using a Micromeritic Autochem 2920 Chemisorption Analyzer apparatus. The completeness of the reduction of the powder was analysed using a temperature programmed reduction (TPR) method. In this experiment, a mixed gas of 20 vol.\% CO in 80 vol.\% nitrogen was introduced into the reaction cell at an effective flow rate of 20 $\mathrm{mL} / \mathrm{min}$. Then, temperature was increased from 40 to $700{ }^{\circ} \mathrm{C}$ with a heating rate of $10{ }^{\circ} \mathrm{C} / \mathrm{min}$ and continued with isothermal reduction at $700{ }^{\circ} \mathrm{C}$ for 30 and 60 minutes.

\section{Characterization}

The crystal structures of the catalysts before and after reactions were determined by XRD's Bruker AXS D8 Advance type. The radiation used was $\mathrm{Cu} \mathrm{K} \alpha(40 \mathrm{kV}, 40 \mathrm{~mA})$ to record the $2 \theta$ diffraction angle from $10^{\circ}$ to $80^{\circ}$ at wavelength $(\lambda=0.154 \mathrm{~nm})$. For identification purposes of crystalline phase composition, diffraction patterns obtained were matched with standard diffraction data (JCPDS) file. The Brunauer-Emmett-Teller (BET) surface areas of the catalysts were measured using a Micromeritics ASAP 2010 instrument after the catalyst was evacuated at $200{ }^{\circ} \mathrm{C}$ for 4 hours. The TEM analysis was performed using a Philips CM12 transmission electron microscope with an electron gun at $200 \mathrm{kV}$. Samples were dispersed in ethanol using supersonic waves and then placed on $\mathrm{Cu}$ grids under atmospheric condition.

\section{RESULT AND DISCUSSION}

\section{A. Characterisation of Undoped and Doped Molybdenum Trioxide, $\mathrm{MoO}_{3}$ Using $\mathrm{XRD}$}

XRD patterns of as prepared undoped and doped $\mathrm{MoO}_{3}$ with 3 and $9 \mathrm{~mol} \% \mathrm{Ni}$ obtained after calcination at $400{ }^{\circ} \mathrm{C}$ for 4 hours are shown in Fig. 1. It shows that molybdenum largely exists as $\mathrm{MoO}_{3}$ (JCPDS 05-0508). With addition of $3 \mathrm{~mol} \%$ $\mathrm{Ni}$ there was a minimal change observed with respect to presence of $\mathrm{NiMoO}_{4}$ (JCPDS 086-0361). Further increased addition of $\mathrm{Ni}$ to $9 \mathrm{~mol} \%$ displays an appearance of crystalline of $\mathrm{NiMoO}_{4}$ which is considered to be the reaction products of $\mathrm{MoO}_{3}$ with $\mathrm{Ni}\left(\mathrm{NO}_{3}\right)_{2} \cdot 6 \mathrm{H}_{2} \mathrm{O}$.

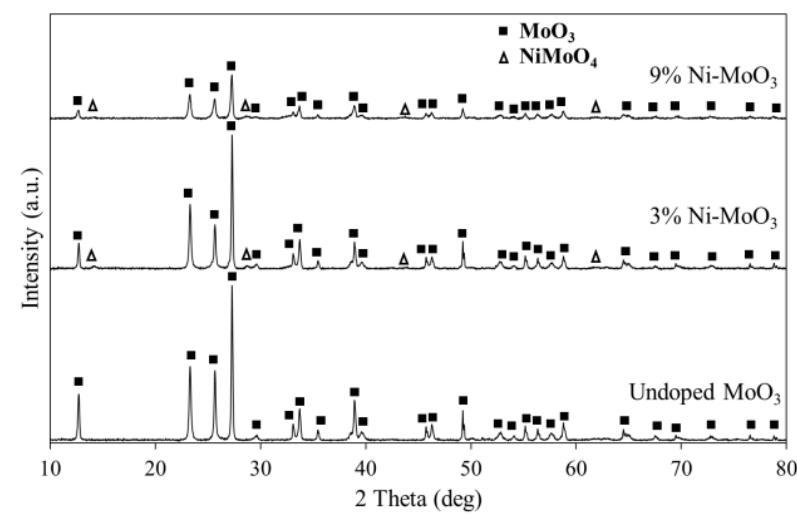

Fig. 1. XRD patterns of the undoped $\mathrm{MoO}_{3}, 3 \% \mathrm{Ni}-\mathrm{MoO}_{3}$ and $9 \% \mathrm{Ni}-\mathrm{MoO}_{3}$ samples obtained after calcination at $400{ }^{\circ} \mathrm{C}$ for 4 hours.

\section{B. Physical Surface Analysis (BET)}

BET analysis of the undoped $\mathrm{MoO}_{3}$ and $\mathrm{Ni}$ doped $\mathrm{MoO}_{3}$ samples are summarized in Table I. Surface area of undoped $\mathrm{MoO}_{3}$ was $6.85 \mathrm{~m}^{2} / \mathrm{g}$ while surface areas of doped $\mathrm{MoO}_{3}$ with 3 and $9 \mathrm{~mol} \% \mathrm{Ni}$ were 11.35 and $19.64 \mathrm{~m}^{2} / \mathrm{g}$ respectively. It was found that the surface area was increased with increasing loading of $\mathrm{Ni}$ to $\mathrm{MoO}_{3}$. This could suggest that there are more active sites that might be attributed to the lower temperature reduction of $\mathrm{MoO}_{3}$ after doping. Hence, Ni addition can significantly increase the surface area of $\mathrm{MoO}_{3}$.

Pore size of undoped $\mathrm{MoO}_{3}$ was $20.36 \mathrm{~nm}$, by addition of $\mathrm{Ni}$ to 3 and $9 \mathrm{~mol} \%$ were 24.89 and $27.75 \mathrm{~nm}$ respectively. It was found that the pore size decreased by increasing of $\mathrm{Ni}$ loading to $\mathrm{MoO}_{3}$. Moreover the pore volume for undoped $\mathrm{MoO}_{3}$ was $0.035 \mathrm{~cm}^{3} / \mathrm{g}$, while by increasing the addition of $\mathrm{Ni}$ 
from 3 to $9 \mathrm{~mol} \%$, the pore volume was increased to 0.071 and $0.087 \mathrm{~cm}^{3} / \mathrm{g}$ respectively.

TABLE I: BET ANALYSIS OF UNDOPED $\mathrm{MOO}_{3}$ AND NICKEL DOPED $\mathrm{MOO}_{3}$

\begin{tabular}{|c|c|c|c|}
\hline Catalyst & $\begin{array}{c}\text { Surface area } \\
\left(\mathrm{m}^{2} / \mathrm{g}\right)\end{array}$ & $\begin{array}{c}\text { Pore size } \\
(\mathrm{nm})\end{array}$ & $\begin{array}{c}\text { Pore volume } \\
\left(\mathrm{cm}^{3} / \mathrm{g}\right)\end{array}$ \\
\hline Undoped $\mathrm{MoO}_{3}$ & 6.85 & 20.36 & 0.035 \\
\hline $3 \% \mathrm{Ni}-\mathrm{MoO}_{3}$ & 11.35 & 24.89 & 0.071 \\
\hline $9 \% \mathrm{Ni}-\mathrm{MoO} 3$ & 19.64 & 27.75 & 0.087 \\
\hline
\end{tabular}

\section{Surface Morphology by TEM}

An investigation on structural of doped catalysts was attempted with TEM. Fig. 2 shows TEM image of undoped $\mathrm{MoO}_{3}$ and doped $\mathrm{MoO}_{3}$ with $\mathrm{Ni}$ samples. It seems that the powder can be clearly differentiated because of the different particle sizes of support $\left(\mathrm{MoO}_{3}\right)$ and dope $(\mathrm{Ni}) . \mathrm{MoO}_{3}$ cluster comprised larger molecule compared to Ni cluster. Tiny spots were revealed in the images which represent $\mathrm{Ni}$ cluster that were seen located around the $\mathrm{MoO}_{3}$ particles. It showed that the $\mathrm{Ni}$ was successfully intercalated into $\mathrm{MoO}_{3}$ powder during impregnation process. Moreover, effect of addition of 3 and 9 mol\% $\mathrm{Ni}$ resulted in presence of new peaks of $\mathrm{Ni}$ which is supported with XRD result shown in Fig. 1.
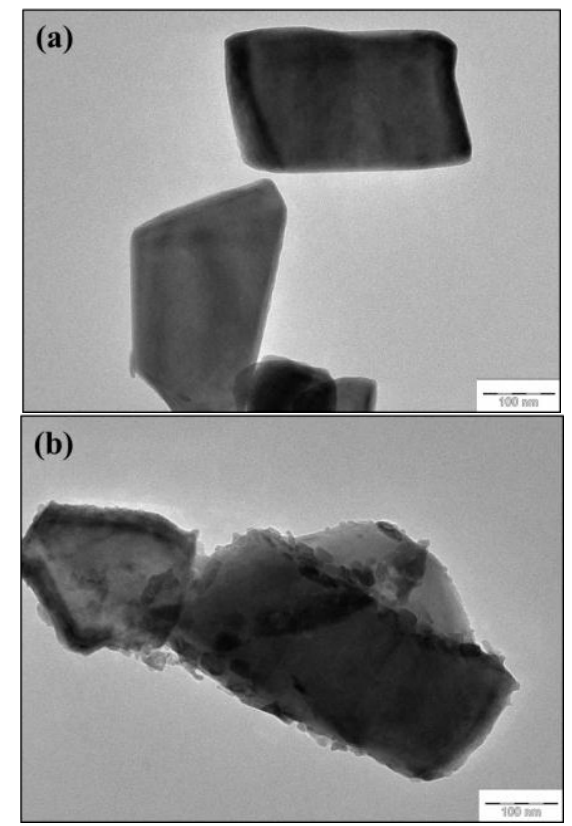

Fig. 2. TEM images of (a) undoped $\mathrm{MoO}_{3}$ (b) $3 \% \mathrm{Ni}-\mathrm{MoO}_{3}$ calcined at $400{ }^{\circ} \mathrm{C}$ for 4 hours.

\section{Temperature Programmed Reduction (TPR)}

Reduction of $\mathrm{MoO}_{3}$ to $\mathrm{MoO}_{2}$ needs to complete at temperature lower than its melting point $\left(795^{\circ} \mathrm{C}\right)$ since $\mathrm{MoO}_{3}$ will end up as an alloy fused mass when it is taken to its melting point [8]. The reduction behaviour of undoped $\mathrm{MoO}_{3}$ sample and $\mathrm{Ni}$ (3 and $9 \mathrm{~mol} \%$ ) doped $\mathrm{MoO}_{3}$ samples was studied using TPR. Fig. 3 shows the TPR profile of nonisothermal reduction until $700{ }^{\circ} \mathrm{C}$ continued with isothermal reduction at $700{ }^{\circ} \mathrm{C}$ for 60 minutes by using $20 \%$ $\mathrm{CO}$ in nitrogen.

The TPR profile of undoped $\mathrm{MoO}_{3}$ sample represents two reduction stages (denoted I and II) which stage I owing to peak displayed at early reaction time may regard to the reduction of $\mathrm{MoO}_{3}$ to $\mathrm{Mo}_{4} \mathrm{O}_{11}$, while stage II is subsequent to reduction steps of $\mathrm{Mo}_{4} \mathrm{O}_{11}$ to $\mathrm{MoO}_{2}$. Meanwhile, with excess of $\mathrm{CO}$ brings to the formation of $\mathrm{Mo}_{2} \mathrm{C}$ [12], [13]. The profile monitor $\mathrm{CO}$ consumption peaks by using $20 \mathrm{vol} . \%$ of $\mathrm{CO}$ in nitrogen which started at about $630{ }^{\circ} \mathrm{C}$ was pointed to the first stage of reduction in agreement with [3], as mentioned that the $\mathrm{MoO}_{3}$ is firstly reduced to $\mathrm{Mo}_{4} \mathrm{O}_{11}$, then to $\mathrm{MoO}_{2}$. After continuing the reaction with isothermal reduction at $700{ }^{\circ} \mathrm{C}$ for 60 minutes, new peak started forming at minutes 40 due to sample changes that occurred, reflecting to second stage reduction of $\mathrm{Mo}_{4} \mathrm{O}_{11}$ to $\mathrm{MoO}_{2}$.

On the other hand, Fig. 3 also indicates clearly that the reduction process of doped $\mathrm{MoO}_{3}$ with 3 and $9 \mathrm{~mol} \%$ of $\mathrm{Ni}$ can be divided into two stages. In each stage, there is a peak of $\mathrm{CO}$ consumption and the TPR peaks have been shifted to lower temperatures. By additional $3 \mathrm{~mol} \%$ of $\mathrm{Ni}$, the reduction peaks are leading to low temperature to $570{ }^{\circ} \mathrm{C}$, while second peak can be monitored after 20 minutes, starting off with isothermal reduction at $700{ }^{\circ} \mathrm{C}$. Then, for the reduction of doped $\mathrm{MoO}_{3}$ with $9 \mathrm{~mol} \%$ of Ni, TPR profile is almost similar showing two peaks where the first reduction peak starts at about $460{ }^{\circ} \mathrm{C}$ which is much lower compared to undoped $\mathrm{MoO}_{3}$, while the second peak started forming at minutes 10 during isothermal reduction at $700{ }^{\circ} \mathrm{C}$.

From Fig. 3, it may be concluded that the reduction of $\mathrm{MoO}_{3}$ is observed to occur with a shift to lower temperature by increasing of additions of $\mathrm{Ni}$. It could be found that doping with $\mathrm{Ni}$ had a remarkable influence on the reduction process of the $\mathrm{MoO}_{3}$ by improving their oxygen storage capacity and reducibility. The strong interaction between nickel ions and molybdenum ions in the samples leads to changes in the coordination environment of molybdenum and the strength of Mo-O bonds [10]. The catalytic effect of $\mathrm{Ni}$ which enhances $\mathrm{CO}$ absorption and $\mathrm{C}$ deposition also causes the decreasing of reduction temperature [14]. The phases formed after the reduction by TPR were analysed by recording XRD pattern of the residual obtained after selected reduction condition.

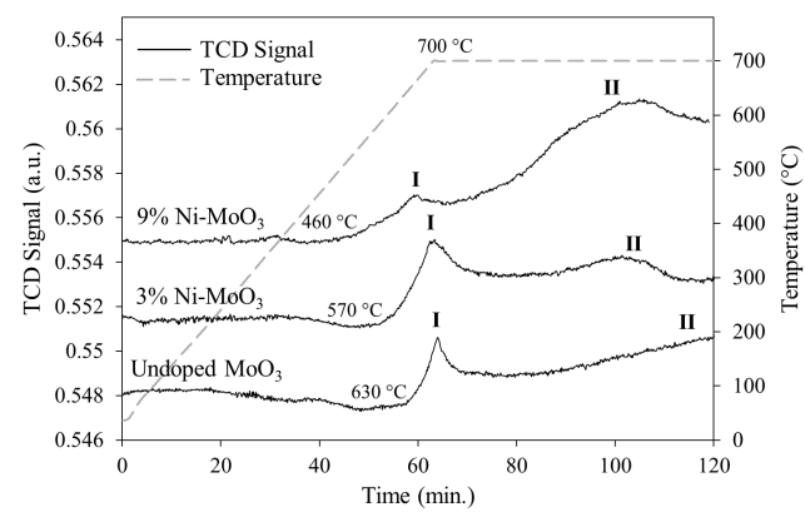

Fig. 3. TPR profile of undoped $\mathrm{MoO}_{3}, 3 \% \mathrm{Ni}-\mathrm{MoO}_{3}$ and $9 \% \mathrm{Ni}-\mathrm{MoO}_{3}$ samples under 20 vol. $\% \mathrm{CO}$ at $40-700{ }^{\circ} \mathrm{C}$ and then hold at $700{ }^{\circ} \mathrm{C}$ for 60 minutes.

\section{E. Reduction Based on Crystallinity}

To investigate the reduction behaviour of $\mathrm{MoO}_{3}$ by using 20 vol. $\%$ CO in 80 vol. $\%$ nitrogen, the samples were collected and XRD patterns were measured. The XRD profile obtained in Fig. 4 revealed the undoped $\mathrm{MoO}_{3}$ sample was not yet reduced to $\mathrm{MoO}_{2}$ even after flowing with 20 vol.\% of $\mathrm{CO}$ until $700{ }^{\circ} \mathrm{C}$. It is due to insufficiency of $\mathrm{CO}$ and heat supply 
to the reaction. Since undoped $\mathrm{MoO}_{3}$ is not completely reduced to $\mathrm{MoO}_{2}$ after nonisothermal reduction until $700{ }^{\circ} \mathrm{C}$, reaction continued with isothermal reduction with $20 \mathrm{vol} . \%$ of $\mathrm{CO}$ in 80 vol. $\%$ of nitrogen at $700{ }^{\circ} \mathrm{C}$ for 30 minutes. From the XRD profile obtained in Fig. 4, it is seen that the complete reduction to $\mathrm{MoO}_{2}$ was not achieved. However, the $\mathrm{MoO}_{2}$ (JCPDS 76-1807) peaks start to appear and $\mathrm{MoO}_{3}$ (JCPDS 74-7383) peaks nearly disappear. Most of the peaks are intermediate phases of $\mathrm{Mo}_{4} \mathrm{O}_{11}$ (JCPDS 89-0687). It is comparable with literature reported by [15] that suggested formation of $\mathrm{Mo}_{4} \mathrm{O}_{11}$ as the earliest reduction of $\mathrm{MoO}_{3}$. As it is shown in Fig. 4, undoped $\mathrm{MoO}_{3}$ was completely reduced to $\mathrm{MoO}_{2}$ after increasing isothermal reduction at $700{ }^{\circ} \mathrm{C}$ for 60 minutes.

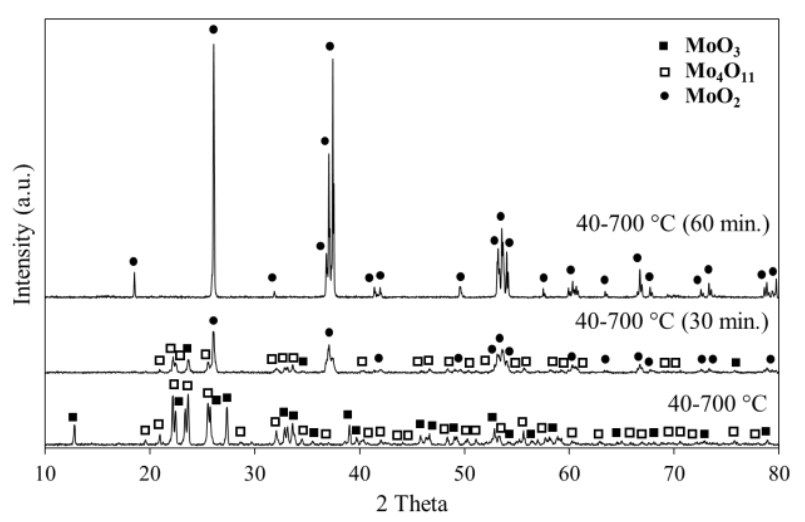

Fig. 4. XRD patterns of reduction of undoped $\mathrm{MoO}_{3}$ sample with 20 vol.\% $\mathrm{CO}$ in nitrogen until $700{ }^{\circ} \mathrm{C}$ and hold at $700{ }^{\circ} \mathrm{C}$ for 30 and 60 minutes.

The comparison of XRD pattern for the nonisothermal reduction of 3 and $9 \mathrm{~mol} \% \mathrm{Ni}-\mathrm{MoO}_{3}$ samples with $20 \mathrm{vol} . \%$ $\mathrm{CO}$ in nitrogen until $700{ }^{\circ} \mathrm{C}$ is shown in Fig. 5. Analysis of the patterns revealed, the reduction product of 3 and 9 mol\% $\mathrm{Ni}-\mathrm{MoO}_{3}$ samples were rather similar with formation of intermediate phases of $\mathrm{Mo}_{4} \mathrm{O}_{11}$ and a few peaks of $\mathrm{NiMoO}_{4}$ (JCPDS 086-0361). However, reduction products of $3 \mathrm{~mol} \%$ $\mathrm{Ni}-\mathrm{MoO}_{3}$ sample showed some remaining unreduced $\mathrm{MoO}_{3}$ peaks but are less than undoped $\mathrm{MoO}_{3}$ sample. For $9 \mathrm{~mol} \%$ $\mathrm{Ni}-\mathrm{MoO}_{3}$ sample, no remaining unreduced $\mathrm{MoO}_{3}$ peaks observed. It can be seen that additional of $\mathrm{Ni}$ is capable to speedup the reduction process of $\mathrm{MoO}_{3}$.

As shown in Fig. 5, doped $\mathrm{MoO}_{3}$ with $\mathrm{Ni}$ is not completely reduced to $\mathrm{MoO}_{2}$ even after nonisothermal reduction until $700{ }^{\circ} \mathrm{C}$. To complete the reduction, reaction continued with isothermal reduction with $20 \mathrm{vol} . \%$ of $\mathrm{CO}$ in $80 \mathrm{vol} . \%$ of nitrogen at $700{ }^{\circ} \mathrm{C}$ for 30 minutes. XRD profile obtained in Fig. 6 shows that the complete reduction to $\mathrm{MoO}_{2}$ was achieved by addition of $9 \mathrm{~mol} \%$ of $\mathrm{Ni}$ to $\mathrm{MoO}_{3}$. Meanwhile, for $3 \mathrm{~mol} \% \mathrm{Ni}-\mathrm{MoO}_{3}$ sample, the $\mathrm{MoO}_{2}$ peaks start to appear and $\mathrm{MoO}_{3}$ peaks completely disappear. Most of the peaks are intermediate phases of $\mathrm{Mo}_{4} \mathrm{O}_{11}$. Moreover, a few peaks of $\mathrm{NiMoO}_{4}$ observed in both samples and new peaks of $\mathrm{Mo}_{0.09} \mathrm{Ni}_{0.91}$ (JCPDS 071-9766) observed in $9 \mathrm{~mol} \%$ $\mathrm{Ni}-\mathrm{MoO}_{3}$ sample. It could be found that by doping with 9 mol\% of $\mathrm{Ni}$, complete reduction would be achieved only after 30 minutes, with the starting of isothermal reduction process compared with undoped $\mathrm{MoO}_{3}$ sample that would take about 60 minutes of isothermal reduction to completely reduce to $\mathrm{MoO}_{2}$.

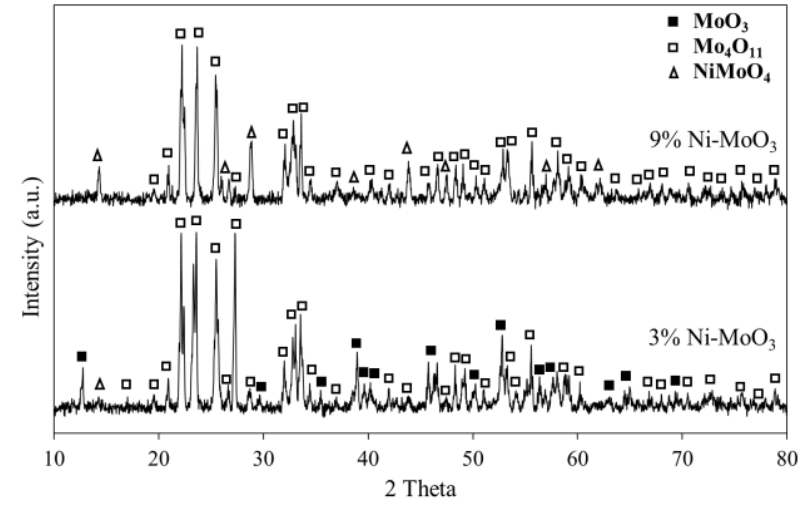

Fig. 5. XRD patterns of nonisothermal reduction of $3 \% \mathrm{Ni}-\mathrm{MoO}_{3}$ and $9 \%$ $\mathrm{Ni}-\mathrm{MoO}_{3}$ samples with $20 \mathrm{vol} \% \mathrm{CO}$ in nitrogen until $700{ }^{\circ} \mathrm{C}$.

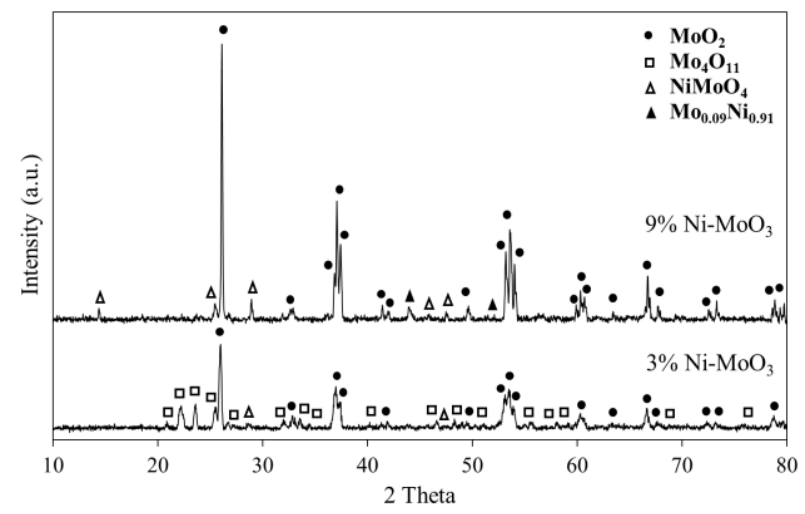

Fig. 6. XRD patterns of nonisothermal reduction of $3 \% \mathrm{Ni}-\mathrm{MoO}_{3}$ and $9 \%$ $\mathrm{Ni}-\mathrm{MoO}_{3}$ samples with $20 \% \mathrm{CO}$ in nitrogen until $700{ }^{\circ} \mathrm{C}$ and hold at $700{ }^{\circ} \mathrm{C}$ for 30 minutes.

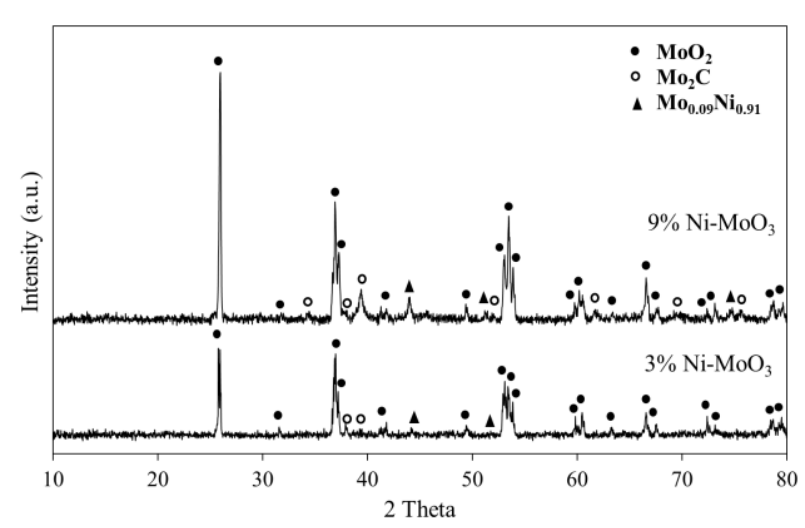

Fig. 7. XRD patterns of nonisothermal reduction of $3 \% \mathrm{Ni}-\mathrm{MoO}_{3}$ and $9 \%$ $\mathrm{Ni}-\mathrm{MoO}_{3}$ samples with 20 vol. $\% \mathrm{CO}$ in nitrogen until $700{ }^{\circ} \mathrm{C}$ and hold at $700{ }^{\circ} \mathrm{C}$ for 60 minutes.

Referring to results in Fig. 6, 3 mol\% $\mathrm{Ni}-\mathrm{MoO}_{3}$ sample is not completely reduced to $\mathrm{MoO}_{2}$. Therefore, isothermal reduction was increased to another 30 minutes. Since the 9 mol\% Ni- $\mathrm{MoO}_{3}$ sample was completely reduced to $\mathrm{MoO}_{2}$, effect of excess of $\mathrm{CO}$ was studied. Fig. 7 shows the XRD patterns of isothermal reduction of 3 and $9 \mathrm{~mol} \% \mathrm{Ni}-\mathrm{MoO}_{3}$ samples for 60 minutes by using $20 \mathrm{vol} \% \mathrm{CO}$ in nitrogen. As it is shown, $3 \mathrm{~mol} \% \mathrm{Ni}-\mathrm{MoO}_{3}$ samples were completely reduced to $\mathrm{MoO}_{2}$ after isothermal reduction for 60 minutes. Peaks of $\mathrm{NiMoO}_{4}$ completely disappeared and peaks of $\mathrm{Mo}_{0.09} \mathrm{Ni}_{0.91}$ are observed in both samples. Somehow, Fig. 7 shows the formation of carbide will take place when excess of $\mathrm{CO}$ was introduced to the system. This was confirmed by the XRD patterns of both samples which displayed a new 
formation peaks of $\mathrm{Mo}_{2} \mathrm{C}$ (JCPDS 071-0242) when the isothermal reduction prolongs until 60 minutes. XRD patterns match well to previously reported pattern for processing of $\mathrm{Mo}_{2} \mathrm{C}[16]$.

Based on the characterization of the reaction products using XRD, it is concluded that the reduction of $\mathrm{MoO}_{3}$ to $\mathrm{MoO}_{2}$ by $\mathrm{CO}$ consists of two reduction stages, namely, $\mathrm{Mo}^{6+}$ $\rightarrow \mathrm{Mo}^{5+}$ and $\mathrm{Mo}^{5+} \rightarrow \mathrm{Mo}^{4+}[10]$. Reduction of $\mathrm{MoO}_{3}$ to $\mathrm{MoO}_{2}$ was a consecutive reaction with the intermediate product $\mathrm{Mo}_{4} \mathrm{O}_{11}$. By addition of $\mathrm{Ni}$, the completed reduction to $\mathrm{MoO}_{2}$ becomes faster compared to undoped $\mathrm{MoO}_{3}$ samples. The $\mathrm{MoO}_{2}$ peaks sharply increase and intermediate $\mathrm{Mo}_{4} \mathrm{O}_{11}$ phases become less and totally disappear. With excess of $\mathrm{CO}$ supplied, $\mathrm{Mo}_{2} \mathrm{C}$ formation will take place. It can be seen that doping with nickel has a remarkable influence in the reduction process of the $\mathrm{MoO}_{3}$.

\section{CONCLUSION}

The reduction behaviour of undoped $\mathrm{MoO}_{3}$ and $\mathrm{Ni}$ doped $\mathrm{MoO}_{3}$ samples were investigated and compared using TPR technique and characterized by XRD, BET and TEM analysis The findings in this research revealed that reduction reaction of $\mathrm{MoO}_{3}$ obeys the consecutive mechanism, namely, $\mathrm{MoO}_{3}$ is firstly reduced to $\mathrm{Mo}_{4} \mathrm{O}_{11}$ and then $\mathrm{Mo}_{4} \mathrm{O}_{11}$ is reduced to $\mathrm{MoO}_{2}$. Furthermore, addition of $\mathrm{Ni}$ to $\mathrm{MoO}_{3}$ give higher surface area and for TEM it is clearly shown the Ni was well disperse on the surface of $\mathrm{MoO}_{3}$. The addition of $\mathrm{Ni}$ to the $\mathrm{MoO}_{3}$ shifted the TPR peaks to the lower temperature side. It can be concluded that the reduction temperature of $\mathrm{MoO}_{3}$ decreased by increasing $\mathrm{Ni}$ addition. $\mathrm{Ni}$ change the coordination environment of molybdenum and the strength of Mo-O bonds, leading to a decrease of the reduction temperature of doped $\mathrm{MoO}_{3}$.

\section{ACKNOWLEDGMENT}

The authors wish to thank Malaysia Ministry of Higher Education (MOHE) and Universiti Pertahanan Nasional Malaysia (UPNM) for funding staff scholarships and also Universiti Kebangsaan Malaysia (UKM) for funding this project under research grant number FRGS/2/2013/TK06/ UKM/02/3, BKBP-FST-K003323-2014, ETP-2013-066, TD-2014-024 and Centre of Research and Innovation Management (CRIM) for the instruments facilities.

\section{REFERENCES}

[1] J. Dang, G.-H. Zhang, and K.-C. Chou, "Study on kinetics of hydrogen reduction of $\mathrm{MoO}_{2}$," Int. J. Refract. Met. Hard Mater., vol. 41, pp. 356-362, 2013.

[2] K. Manukyan, D. Davtyan, J. Bossert, and S. Kharatyan, "Direct reduction of ammonium molybdate to elemental molybdenum by combustion reaction," Chem. Eng. J., vol. 168, no. 2, pp. 925-930, 2011.

[3] J. Dang, G.-H. Zhang, K.-C. Chou, R. G. Reddy, Y. He, and Y. Sun, "Kinetics and mechanism of hydrogen reduction of $\mathrm{MoO}_{3}$ to $\mathrm{MoO}_{2}$," Int. J. Refract. Met. Hard Mater., vol. 41, pp. 216-223, Nov. 2013.

[4] M. Saghafi, S. Heshmati-Manesh, A. Ataie, and A. A. Khodadadi, "Synthesis of nanocrystalline molybdenum by hydrogen reduction of mechanically activated $\mathrm{MoO}_{3}$," Int. J. Refract. Met. Hard Mater., vol. 30, no. 1, pp. 128-132, Jan. 2012.

[5] R. K. Enneti and T. A. Wolfe, "Agglomeration during reduction of $\mathrm{MoO}_{3}$," Int . Journal of Refractory Metals and Hard Materials, vol. 31 , pp. 47-50, 2012.
[6] W. V Schulmeyer and H. M. Ortner, "Mechanisms of hydrogen reduction of molybdenum oxides," Met. Powder Rep., vol. 58, p. 33, 2003.

[7] B.-S. Kim, E. Kim, H.-S. Jeon, H.-I. Lee, and J.-C. Lee, "Study on the reduction of molybdenum dioxide by hydrogen," Mater. Trans., vol. 49, no. 9, pp. 2147-2152, 2008 .

[8] M. Saghafi, A. Ataie, and S. Heshmati-Manesh, "Effects of mechanical activation of $\mathrm{MoO}_{3} / \mathrm{C}$ powder mixture in the processing of nano-crystalline molybdenum," Int. J. Refract. Met. Hard Mater., vol. 29, no. 4, pp. 419-423, Jul. 2011.

[9] V. V. Satyajeet Chaudhury, S. K. Mukerjee, and V. N. Vaidya, "Kinetics and mechanism of carbothermic reduction of $\mathrm{MoO}_{3}$ to $\mathrm{Mo}_{2} \mathrm{C}$," J. Alloys Compd., vol. 261, pp. 105-113, 1997.

[10] J. Wang, Z. Ren, W. Liu, F. Gao, and M. Zhou, "Effects of $\mathrm{RE}_{2} \mathrm{O}_{3}$ doping on the reduction behavior of molybdenum oxide and properties of molybdenum powder," Int. J. Refract. Met. Hard Mater., vol. 27, no. 1, pp. 155-158, Jan. 2009.

[11] T. A. Zepeda, B. Pawelec, J. L. G. Fierro, A. Olivas, S. Fuentes, and T Halachev, "Effect of Al and Ti content in HMS material on the catalytic activity of NiMo and CoMo hydrotreating catalysts in the HDS of DBT," Microporous Mesoporous Mater., vol. 111, no. 2008 , pp. 157-170, 2008.

[12] H.-Y. Zhu, Z.-B. Li, H.-S. Yang, and L.-G. Luo, "Carbothermic reduction of $\mathrm{MoO}_{3}$ for direct alloying process," J. Iron Stell Res., vol 20, no. 10, pp. 51-56, 2013.

[13] A. Samsuri, T. Shafazila, T. Saharuddin, F. Salleh, M. Wahab, M. Hisham, R. Othaman, and M. A. Yarmo, "Reduction of $\mathrm{MoO}_{2}$ to metallic molybdenum via carburization and thermal process," Adv. Mater. Res., vol. 1087, pp. 64-67, 2015.

[14] H. Mohammadzadeh, H. Rezaie, H. Samim, M. Barati, and H. Razavizadeh, "Reduction and carburization behavior of $\mathrm{NiO}-\mathrm{WO}_{3}$ mixtures by carbon monoxide," Thermochimica Acta, vol. 590, pp 210-218, 2014

[15] E. Lalik, "Kinetic analysis of reduction of $\mathrm{MoO}_{3}$ to $\mathrm{MoO}_{2}$," Catal. Today, vol. 169, pp. 85-92, 2011.

[16] J. B. Claridge, A. P. E. York, A. J. Brungs, C. Marquez-alvarez, J. Sloan, S. C. Tsang, and M. L. H. Green, "New catalysts for the conversion of methane to synthesis gas: Molybdenum and tungsten carbide," J. Catal., vol. 180, pp. 85-100, 1998.

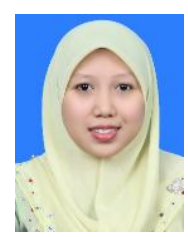

Alinda Samsuri was born on August 21, 1986 in Batu Pahat, Johor, Malaysia. She earned her bachelor of science degree in analytical and environmental chemistry from Universiti Malaysia Terengganu (UMT), Malaysia in 2008 and her master of science degree in analytical chemistry and instrumental analysis from Universiti Malaya (UM), Malaysia in 2010.

She has been a tutor of the Centre for Defence Foundation Studies, Universiti Pertahanan Nasional Malaysia (UPNM), Malaysia since 2011. She experienced work as Product Development Technologies with Fonterra Brands Malaysia for 2 years. She is currently a full time $\mathrm{PhD}$ candidate at School of Chemical Sciences and Food Technology, Faculty of Science and Technolgy, Universiti Kebangsaan Malaysia (UKM), Malaysia. Her research interests are in field of hydrogen production as a renewable energy by photocatalysis water splitting, thermocatalysis water splitting and electrolysis of water. She also interested in the development of heterogeneous catalyst.

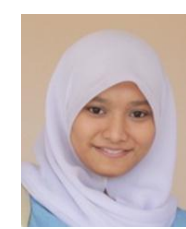

Fairous Salleh was born on May 20, 1983 in Kuantan, Pahang, Malaysia. She obtained her bachelor of science degree with honours in resource chemistry from Universiti Malaysia Sarawak (UNIMAS), Malaysia in 2005, and her master of science by research from Universiti Teknologi Mara Malaysia (UiTM), Malaysia in 2011.

She is currently a full time PhD candidate at School of Chemical Sciences and Food Technology, Faculty of Science and Technology, Universiti Kebangsaan Malaysia (UKM). She experienced work as Lecturer in Kolej Teknolgi Timur (KTT), Sepang, Malaysia for almost 2 years. Her research interests are in photocatalysis water splitting, thermocatalysis water splitting and electrolysis of water. She also interested in the catalytic gasification and pyrolysis, fuel and energy recovery from waste and waste-to-wealth

She had won several awards including silver medal in Invention, Innovation and Design, R\&D Competition by Universiti Teknologi Mara Malaysia (UiTM) 2009. 


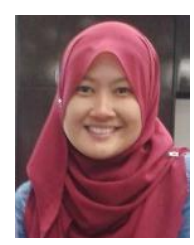

Tengku Shafazila Tengku Saharuddin was born on 5 February, 1983 in Grik, Perak, Malaysia. She earned his bachelor of science degree in petroleum chemistry from Universiti Putra Malaysia (UPM), Malaysia in 2005 and master of science degree by research from Universiti Teknologi Mara Malaysia (UiTM), Malaysia in 2012.

She is currently a third year doctoral student at School of Chemical Science and Food Technology, Faculty of Science and Technology, Universiti Kebangsaan Malaysia (UKM). She experienced working as a chemistry lecturer at Kolej Teknologi Timur (KTT), Sepang, Malaysia for 2 years. Her research interests are in areas of water splitting for hydrogen production, renewable energy, reaction kinetics, reaction mechanisms and heterogeneous catalysts development.

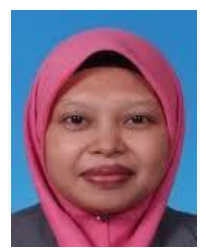

Rizafizah Othaman obtained her bachelor degree in chemical engineering from Tokyo Institute of Technology, Japan in 1999, master degree in chemical engineering and process from Universiti Kebangsaan Malaysia (UKM), Malaysia in 2004 and doctor of engineering degree from Tokyo Institute of Technology, Japan in 2010.

She is currently a senior lecturer and the head of the Chemical Technology Programme at School of Chemical Sciences and Food Technology, Faculty of Science and Technology, UKM. She experienced work as a chemical engineer specialized in electroless NiP plating with Showa Aluminium Malaysia for 2 years before being offered as chemistry lecturer at Japanese Associate Degree programme (JAD), a twinning programme for higher education between YPM Malaysia and Japan Universities Consortium. Her research interests are in the field of polymeric membrane development for renewable energy applications, wastewater treatments and gas separation, process development via catalysis and chemistry outreach and education.

Dr. Rizafizah Othaman is also a fellow member of Polymer Research Centre and The Centre for Water Research and Analysis (ALIR) at UKM. She is a registered engineer with Board of Engineers Malaysia. She was awarded with Monbukagakusho Scholarship from Japanese Government during her PhD study. She had won several awards including silver medal in Brussel INOVA 2013 Competition and Bronze in PECIPTA 2013.

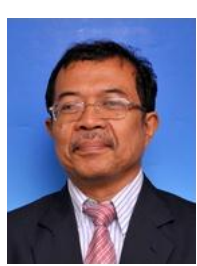

Mohd. Ambar Yarmo received his bachelor of science degree in chemistry from Universiti Kebangsaan Malaysia (UKM), Malaysia and his doctor of philosophy degree in analytical chemistry from University of Wales, Cardiff, United Kingdom.

He is currently a professor at School of Chemical Sciences and Food Technology, Faculty of Science and Technology, UKM. He has attended to Japanese Scientific Exchange Programme under JSPS-VCC Programme (1988). He was a visiting scientist at Petronas Research and Scientific Services (1995). He has Research collaboration with Fritz Haber Institute, Max Planck Society, Berlin, Germany (2002). He was the Outstanding UKM Lecturer in Research and Teaching (2000, 2002 and 2005). His research interests are in conversion of $\mathrm{CO}_{2}$ to Fuel, bio-ethanol derivatives and biofuel applications, upgrading of natural gas and palm oil to higher added value specialty chemicals using combinatorial technologies and catalysis.

Prof. Dr. Mohd. Ambar Yarmo is the chairman of Xapp-MNS (X-ray Application Society), Malaysia Nuclear Society. He is a senior member of International Zeolite Association (IZA, USA), Malaysian Analytical Member Society (ANALIST) and Malaysian Nuclear Society. 